\title{
Wave Energy in Tropical Regions: Deployment Challenges, Environmental and Social Perspectives
}

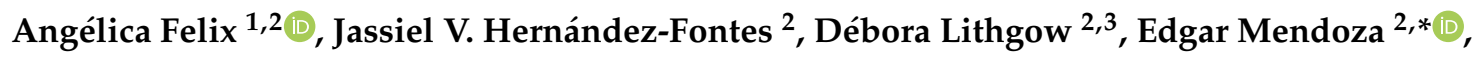 \\ Gregorio Posada ${ }^{4}$, Michael Ring ${ }^{2}$ and Rodolfo Silva ${ }^{2}$ \\ 1 National Council of Science and Technology, Mexico City 03940, Mexico \\ 2 Institute of Engineering, National Autonomous University of Mexico, Mexico City 04510, Mexico \\ 3 Environment and Sustainability Network, Institute of Ecology, Xalapa 91070, Mexico \\ 4 EPOMEX Institute, Campeche Autonomous University, San Francisco de Campeche 24095, Mexico \\ * Correspondence: emendozab@iingen.unam.mx
}

Received: 5 June 2019; Accepted: 6 July 2019; Published: 14 July 2019

\begin{abstract}
The harnessing of renewable sources of marine energy has become a promising solution for a number of problems, namely satisfying the increasing demand for electricity, the reduction of greenhouse gas emissions, and the provision of energy to regions unconnected to a national grid. Tropical countries have an interesting dichotomy: Despite their varied potential sources of marine energy, their environmental and social conditions impose severe constraints on the development of a renewable energy industry. Moreover, the exploitation of these opportunities is limited by national economies' reliance on fossil fuels, political and social restraints, and technological immaturity. The present work addresses challenges and opportunities common to wave energy implementation in tropical nations, as a first approach to a regional diagnosis. The motivation for this work is to encourage research on wave energy policies in the Tropics. Technical, environmental, and social challenges to be overcome in wave energy projects are discussed. The technical challenges are grouped into development, deployment, and operation stages of wave energy converters; environmental challenges are divided into biodiversity, cumulative effects, and monitoring aspects, whilst social issues include population growth and energy access matters. The Mexican strategy for developing sustainable technology throughout the wave energy production chain is also presented.
\end{abstract}

Keywords: wave energy; tropical regions; challenges; social perspectives

\section{Introduction}

The extraction of energy from sources available in the oceans is an alternative to fossil fuels. Some means of harnessing this energy include: Floating or fixed devices, which convert wave motion [1-5]; turbines or oscillatory devices, which take advantage of ocean and tidal currents [5,6]; thermal plants, which use temperature differences of the water along the vertical column to run Rankine systems [7-9]; and salinity gradient plants, which recover part of the energy released during the mixing of two solutions with different salt concentration $[10,11]$. Without disregarding the environmental, economic, and social constraints that may affect the costs involved in the extraction, the degree of success in extracting these types of energies depends on the long-term availability of the energy source and the suitability of the sites chosen for the deployment of devices.

According to the Ocean Energy Systems Technology Collaboration Programme [12], 180 ocean energy facilities exist around the world, 109 are tidal, 58 for waves, 12 for thermal gradient and only one for salinity gradient. For wave energy in particular, around $600 \mathrm{MW}$ are installed worldwide, although only about $4 \mathrm{MW}$ are fully operating. In general, the economically developed countries lead the field in terms of the maturity of ocean energy extraction technologies. These countries have 
projects and plans for future development based on their local marine characteristics and geographical region; temperate, polar or subpolar. Most developing countries, on the other hand, are located in tropical regions (approximately between latitudes $23.5^{\circ} \mathrm{N}$ and $23.5^{\circ} \mathrm{S}$ ), where it may also be possible to harness marine energy. In these regions stable, high temperatures and air humidity are generally found, although climate variations exist between sub-regions, due to altitude, topography, winds, ocean phenomena, geomorphology, vegetation, and anthropic changes [13].

While the greatest wave energy potential is found outside the Tropics, some tropical countries have lower, but persistent, availability of resources. Indeed, wave energy converters have been successfully deployed in Indonesia [14,15], the Philippines [16], and India [17]. Recently, evaluations of ocean energy resources in tropical regions have been published. In Asia, Purba [14] evaluated the possibilities of taking advantage of ocean energy resources in Indonesia. Through database analyses, they found sites at which ocean surface waves have a mean $72 \mathrm{~kW} / \mathrm{m}^{2}$ available.

Regarding Oceania, Hemer et al. [18] showed that some of the most energetic wave and tidal energy resources are found in the tropical and subtropical regions of this continent. SEA [19] reported that converting energy from waves is feasible along the coast of Southern Africa [20].

In the tropical regions of America, Osorio et al. [21] estimated the available ocean energy resources from waves, tides, currents, salinity gradients, and thermal gradients in Colombia. Recently, Hernández-Fontes et al. [22] performed a theoretical evaluation of ocean energy resources in Mexico, considering the power availability from ocean currents, waves, thermal, and salinity gradients, defining potential locations for the deployment of devices.

In tropical regions, ocean energy resources are available, but many environmental and social constraints have limited the development of local technologies. Tropical climates produce a great diversity of terrestrial and marine life, with most of the world's biodiversity being concentrated here [23], it is therefore imperative to regulate the use of natural resources in these regions. Since most of the countries in tropical regions are still developing and have a wide diversity of people and customs, social constraints cannot be ignored. This paper reviews the technical, environmental, and social aspects related to energy extraction in tropical regions, specifically for wave energy conversion. The main objective is to present aspects that should be considered in the planning and execution of wave energy projects in tropical regions, emphasizing in the technical, ecological, and social challenges that have to be overcome.

The article is divided as follows: Section 2 overviews wave energy in tropical regions, including a review of wave energy resource assessment, a description of devices that could be employed in these regions, and examples of how to select devices for these regions from a qualitative and quantitative perspective. Section 3 presents technical challenges for wave energy harvesting. Ecological and social challenges are described in Section 4. The recently set up Mexican strategy for developing sustainable technology for wave energy harvesting is presented in Section 5. Finally, Section 6 summarizes the main conclusions and recommendations of the present work.

\section{Overview of Wave Energy in Tropical Regions}

\subsection{Resource Availability in Tropical Regions}

Arguably, ocean wave energy has the most potential for technological development, particularly in European waters where high waves are found [24]. Most wave energy conversion projects are found in North European countries, where most wave energy conversion devices have been invented [25]. The coasts off the United Kingdom have the highest power rates 60-70 kW/m [24], while the Norwegian Sea has 40-50 kW/m [26].

Cornett et al. [27] stated that the annual wave power $(\mathrm{kW} / \mathrm{m})$ between the Tropics of Cancer and Capricorn is not as high as that in higher latitudes. In the Tropics, it is common to find up to $20 \mathrm{~kW} / \mathrm{m}$ near the coast and 20-30 kW/m in intermediate and deep waters. Mork et al. [28] included shallow water effects in their analysis, finding similar ranges of annual wave power. Mustapa et al. [1] also 
showed that there is less energy available in Tropical seas. Reports on mean power estimations in tropical regions include: North East Brazil ( 2-14 kW/m, [29]), the South China Sea $(\sim 5.32 \mathrm{~kW} / \mathrm{m},[30])$, the Indian Coast ( 5-10 kW/m, [31]), and the East and West peninsulas of Malaysia ( 6.5 kW/m, [32,33]).

Sannasiraj and Sundar [17] evaluated wave energy resources at 73 locations on the Indian coast, finding a maximum power of $20-25 \mathrm{~kW} / \mathrm{m}$. Aboobacker et al. [34] assessed wave energy power at 12 specific locations along the coasts of the Red Sea, between $\left(12^{\circ} \mathrm{N}-30^{\circ} \mathrm{N}\right)$ and $\left(32^{\circ} \mathrm{E}-44^{\circ} \mathrm{E}\right)$, of which more than $50 \%$ fall in the tropical region. They used numerical modelling and found a highest mean wave power of 6-6.5 kW/m in deep waters. Bernardino et al. [35] examined wave energy resources around the Cape Verde Islands through numerical simulations for a 10-year period (2004-2013). Mean wave power of over $7 \mathrm{~kW} / \mathrm{m}$ was found close to the islands. Recently, Wang et al. [36] evaluated wave energy resources in Southern China (lat: $4^{\circ} \mathrm{N}-24^{\circ} \mathrm{N}$, lon: $105^{\circ} \mathrm{E}-120^{\circ} \mathrm{E}$ ) using databases and performing monthly and seasonal analyses. In winter, the available wave power surpassed $20 \mathrm{~kW} / \mathrm{m}$. Kompor et al. [37] performed an analysis of wave energy resources for 16 specific locations in Thailand. The average power found was lower than $10 \mathrm{~kW} / \mathrm{m}$. Quitoras et al. [16] evaluated wave energy resources using numerical modelling in the Philipines, concluding that the power never exceeds $20 \mathrm{~kW} / \mathrm{m}$.

Rusu and Onea [38] performed a theoretical resource assessment of wave energy worldwide using the ERA-Interim database. The authors chose 11 tropical sites from the four continents to estimate average wave power over a 15-year period (January 2000-December 2014).

In Table 1, it can be seen that the power available at these 11 locations, near to the coasts, the mean wave power density for the tropical zone does not exceed $20 \mathrm{~kW} / \mathrm{m}$. However, the mean values are not necessarily representative of the actual energy available.

Table 1. The 11 sites analyzed to evaluate wave energy potential.

\begin{tabular}{cccccc}
\hline Site & Lon & Lat & Continent & Nearest state & $\begin{array}{c}\text { Total Theoretical } \\
\text { Power (kW/m) }\end{array}$ \\
\hline W1 & $16^{\circ} 12^{\prime} \mathrm{N}$ & $98^{\circ} 34^{\prime} \mathrm{W}$ & America & Oaxaca, Mexico & $0-10$ \\
W2 & $13^{\circ} 00^{\prime} \mathrm{S}$ & $76^{\circ} 42^{\prime} \mathrm{W}$ & America & Lima, Peru & $10-20$ \\
W3 & $23^{\circ} 10^{\prime} \mathrm{S}$ & $41^{\circ} 34^{\prime} \mathrm{W}$ & America & Rio de Janeiro, Brazil & $10-20$ \\
W4 & $14^{\circ} 44^{\prime} \mathrm{N}$ & $17^{\circ} 35^{\prime} \mathrm{W}$ & Africa & Dakar, Senegal & $10-20$ \\
W5 & $6^{\circ} 28^{\prime} \mathrm{S}$ & $11^{\circ} 56^{\prime} \mathrm{E}$ & Africa & Zaire, Angola & $10-20$ \\
W6 & $25^{\circ} 19^{\prime} \mathrm{S}$ & $46^{\circ} 57^{\prime} \mathrm{E}$ & Africa & Anosy, Madagascar & $0-10$ \\
W7 & $7^{\circ} 37^{\prime} \mathrm{N}$ & $77^{\circ} 33^{\prime} \mathrm{E}$ & Asia & Tamil Nadu, India & $0-10$ \\
W8 & $5^{\circ} 12^{\prime} \mathrm{S}$ & $103^{\circ} 38^{\prime} \mathrm{E}$ & Asia & Lampung, Indonesia & $10-20$ \\
W9 & $21^{\circ} 24^{\prime} \mathrm{S}$ & $114^{\circ} 26^{\prime} \mathrm{E}$ & Oceania & Western Australia, & $10-20$ \\
W10 & $3^{\circ} 2^{\prime} \mathrm{S}$ & $142^{\circ} 15^{\prime} \mathrm{E}$ & Asia & Australia & $0-10$ \\
W11 & $13^{\circ} 58^{\prime} \mathrm{N}$ & $124^{\circ} 27^{\prime} \mathrm{E}$ & Asia & New Guinea & $10-20$ \\
\hline
\end{tabular}

In Figure $1 \mathrm{a}, \mathrm{b}$, the persistence of wave energy for 10 and $20 \mathrm{~kW} / \mathrm{m}$, as a percentage of the year, is presented. The theoretical power was estimated following [39] the ERA-Interim database [40] from 1979 to 2017 as seen in Equation (1).

$$
P_{\mathrm{OW}}=\frac{\rho g^{2} T_{01} H_{\mathrm{s}}^{2}}{64 \pi}
$$

where $\rho$ is seawater density $\left(1025 \mathrm{~kg} / \mathrm{m}^{3}\right), H_{s}$ (in m) is the significant wave height or the average height, and $T_{01}$ (in s) is its corresponding energy period. It is worth noting that Equation (1) is valid for deep waters. Figure 1a shows that for low power values, several tropical regions show similar or even more availability on a yearly basis than countries located in higher latitudes. This is evidence that if suitable technology is developed, this energy source can be competitively harnessed. In turn, as shown in Figure $1 \mathrm{~b}$, the power availability rapidly decreases as a function of the power threshold. 

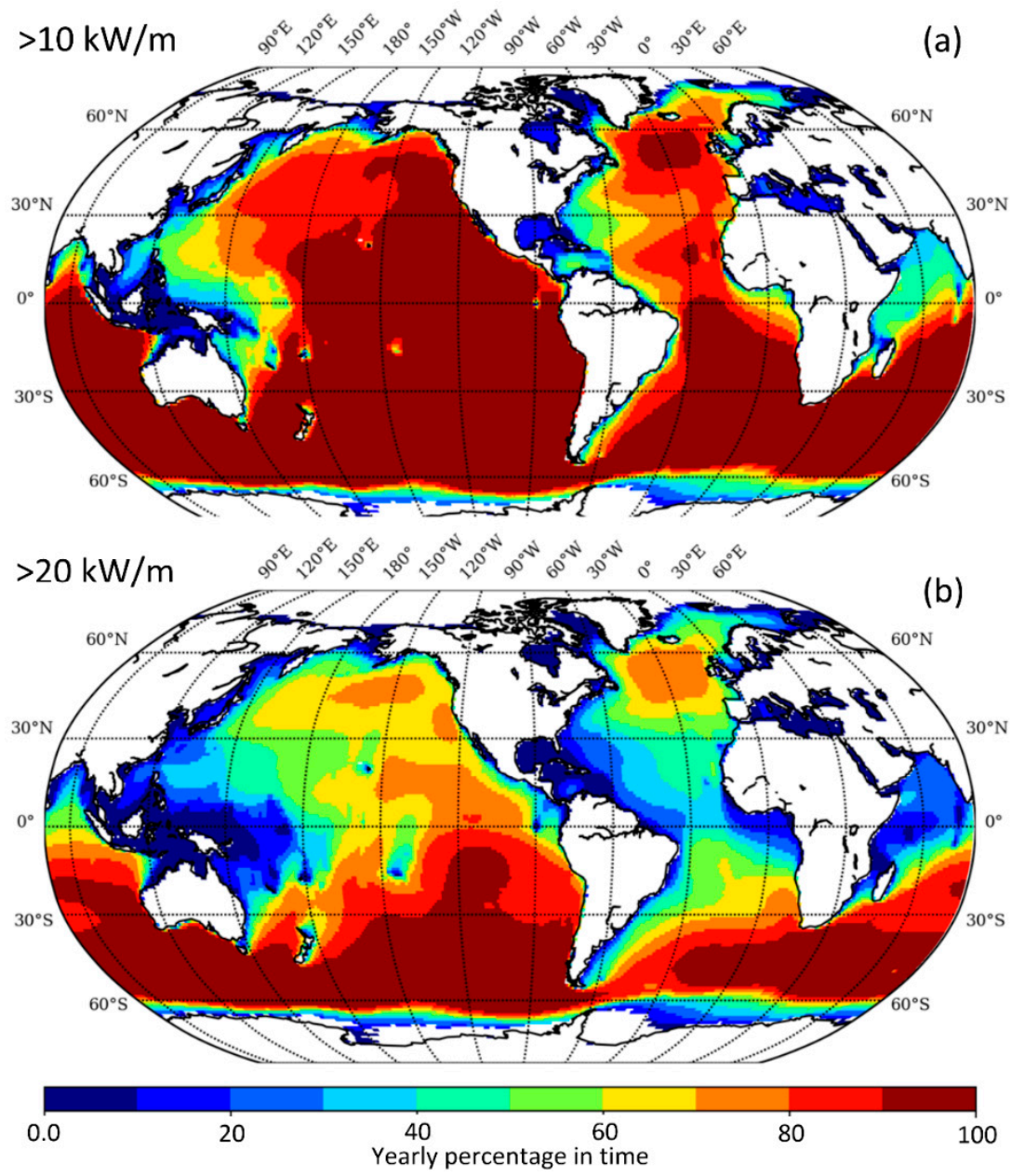

Figure 1. Yearly percentage in time of power equal or greater than: (a) $10 \mathrm{~kW} / \mathrm{m}$ and (b) $20 \mathrm{~kW} / \mathrm{m}$ (bottom).

The computed power values range from 5 to $80 \mathrm{~kW} / \mathrm{m}$ every $5 \mathrm{~kW}$ are available as Supplementary Materials.

The persistence of wave power availability gives useful information for investors, permits better planning of wave energy plants, and facilitates their integration into the electricity market. The results from this analysis were compared with the sites studied by [38]. Figure 2a shows that for some specific areas (W6 and W7), there is the possibility of harvesting more than $20 \mathrm{~kW} / \mathrm{m}$ for around $30 \%$ of the year. In general, $10 \mathrm{~kW} / \mathrm{m}$ power is available at all the sites, with the exception of the east coast of Indonesia and west of Africa, for $80 \%$ of the year.

The results presented suggest that the wave energy available near the coasts of tropical countries does not exceed $40 \mathrm{~kW} / \mathrm{m}$. However, in places like the western coasts of Australia, Peru, and Chile, it is possible to harvest $40 \mathrm{~kW} / \mathrm{m}$ or more and a minimum of $25 \mathrm{~kW} / \mathrm{m}$ up to $30 \%$ and $60 \%$ of the year, respectively.

Exploiting wave energy resources farther from the coasts could be impossible logistically and economically. Thus, it is feasible to begin initial wave energy extraction in tropical regions by deploying efficient devices in the regions with low but persistent energy availability. 

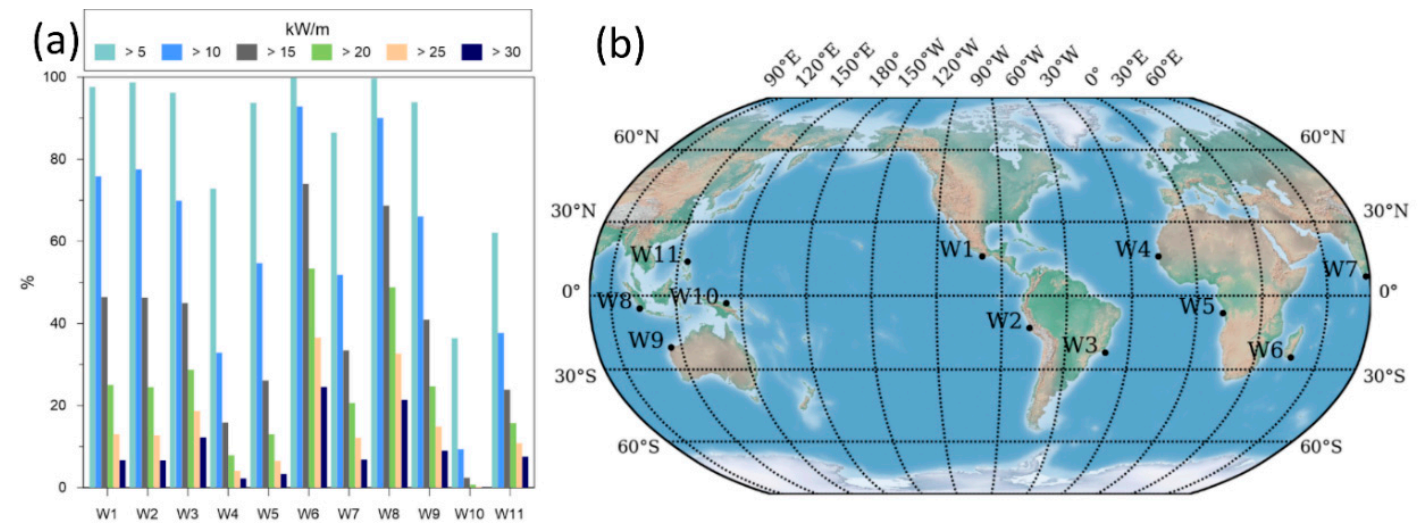

Figure 2. (a) Yearly availability percentage for 5, 10, 15, 20, 25, and $30 \mathrm{~kW} / \mathrm{m}$ for the sites listed in Table 1, (b) location of sites W1-W11.

\subsection{Wave Energy Conversion}

A wave energy converter (WEC) is employed to convert the kinetic and/or potential energy of waves into electric power. The conversion process involves the capture and transmission of the energy to a generator that produces electric power. The type of WEC chosen will depend on the physical characteristics of the specific location, the types of local waves, and their working principles. Considering the classification proposed by Mustapa et al. [1], WECs can be divided into four groups.

- Wave-activated bodies: These partially floating devices are generally arranged parallel to the direction of the waves. Articulated, they follow the motion of the waves and extract energy through hydraulic or mechanical transmission. Floating devices of this type include the Pelamis [6], Anaconda [41], and Salter Duck [42]. Fixed devices of this type include the WaveRoller [43] and Pendulum [44,45].

- Point absorbers: These floating or submerged bodies oscillate relative to the wave motion and are even capable of taking advantage of multi-directional waves. The device consists of a floater and an absorber unit, where the power take-off is connected. Examples of this type of WEC are the AquaBoy [46] and Archimedes [47].

- Oscillating water columns: These WECs capture the pressurized air derived from the oscillation of waves inside a chamber. This air expands and retracts horizontally, activating an air turbine. Floating and fixed examples of this type are the Backward Bent Duct Buoy (BBDB, [48]), the PICO [49], and U-OWC [50].

- Overtopping: This type of device uses the variations in potential energy of a water reservoir to activate a submerged turbine. The variations in potential energy are produced by wave overtopping onto a structure. Floating and fixed devices of this type are the Wave Dragon [51], the Sea Slot-Cone Generator devices [52], and Overtopping Breakwater for Energy Conversion (OBREC, [53]).

The work of Mustapa et al. [1] offers more details about this WEC classification, including the operational depths, operating, and output power ranges. Table 2 summarizes the ranges of these parameters for all the devices discussed in Mustapa's et al. work. From Table 2 it is possible to define the optimum conditions for each type of WEC. The depth range refers to optimal placement depth categories: On-shore (0-10 m), near-shore (10-25 m), and off-shore ( $>40 \mathrm{~m})$. 
Table 2. Summary of operating depths, mean power ranges, and output power ranges for wave energy converter (WEC) devices.

\begin{tabular}{ccccc}
\hline WEC Concept & Type & Depth Range (m) & $\begin{array}{c}\text { Mean Wave Power } \\
\text { Range (kW/m) }\end{array}$ & $\begin{array}{c}\text { Output Power } \\
\text { Range (kW) }\end{array}$ \\
\hline \multirow{2}{*}{ Wave activated body } & Floating & $2-75$ & $10-70$ & $68-2250$ \\
& Fixed & $1-40$ & $10-50$ & $5-100$ \\
\hline \multirow{2}{*}{ Point absorber } & Floating & $10-2500$ & $3.4-80$ & $4-500$ \\
& Fixed & $10-43$ & $2.8-40$ & $221-600$ \\
\hline \multirow{2}{*}{ Oscillating water column } & Floating & $5-50$ & $4-50$ & $153-1500$ \\
& Fixed & $5-14.5$ & $20-60$ & $31.7-2000$ \\
\hline \multirow{2}{*}{ Overtopping } & Floating & $20-40$ & 60 & $625-940$ \\
& Fixed & $6-20$ & $14-30$ & $49-350$ \\
\hline
\end{tabular}

The fourth column of Table 2 shows the mean wave power ranges necessary to activate the different types of devices. As many authors have noted, the wave power available in tropical regions is usually less than $20 \mathrm{~kW} / \mathrm{m}$, therefore fixed and floating point absorber devices and floating oscillating water column devices are the most appropriate for tropical regions, since they operate with $2.8-3.4 \mathrm{~kW} / \mathrm{m}$ and $4 \mathrm{~kW} / \mathrm{m}$, respectively. Point absorber devices might present a power output of 4 to $600 \mathrm{~kW}$, whereas the floating oscillating water column devices might yield 153-1500 kW. However, in some places, it may be possible to use wave activated body devices, where there is mean wave power for almost $80 \%$ of the year; making it possible to obtain between $5-2250 \mathrm{~kW} / \mathrm{m}$.

\subsection{Qualitative Consideration of Devices for Tropical Regions: India}

As described earlier, the selection of an adequate WEC to operate in a particular tropical situation depends on the characteristics of the device, the geomorphology at the deployment location, and the wave power available there. Some authors have discussed these aspects for Colombia [21], Peru [43], and Thailand [37], highlighting that an adequate selection of WECs demands qualitative and quantitative analyses.

From a qualitative point of view, it is possible to consider the case of India as reference to discuss qualitative selection of WECs. Sannasiraj and Sundar [17] proposed specific devices for potential energy generation sites on the Indian coast through a "common sense" approach. Firstly, the location with the greatest power availability in India was examined; Kanyakumari in Tamil Nadu, $8^{\circ} \mathrm{N}, 77^{\circ} \mathrm{E}$, with $\sim 23 \mathrm{~kW} / \mathrm{m}$ mean wave power. The rocky coastal morphology and the fact that the region is reliant on fishing activities, meant there were some restrictions on the locations available. The use of a hybrid wind and wave converter was proposed, similar to the Poseidon device, a device consisting of a floating, hybrid power plant with both a wave energy converter and wind turbines.

For the coast of Andhra Pradesh, Kaviti, $19^{\circ} \mathrm{N}, 85^{\circ} \mathrm{E}$, has $\sim 15 \mathrm{~W} / \mathrm{m}$ power available. The nearshore slope is steep and the seabed is fine silt to clay. Therefore, fixed WEC devices were not considered suitable and devices based on the overtopping concept (e.g., Wave Dragon prototypes) were recommended for deployment, at depths of less than $20 \mathrm{~m}$.

For the short, eroding coast of Puducherry $\left(12{ }^{\circ} \mathrm{N}, 80^{\circ} \mathrm{E}\right)$, with wave power of $\sim 10.5 \mathrm{~kW} / \mathrm{m}$, coupling coastal defense structures with oscillating water column (OWC) devices was recommended. The installation of some point absorber WECs on the coastal structures as a complement was also suggested. Regarding other tropical regions, Alifdini [54] also suggested that OWC devices may be suitable for some potential locations in Indonesia.

The qualitative strategy presented by Sannasiraj and Sundar [17] for the Indian coast can be extended or adapted for other types of hybrid structures, designed for wave energy extraction, in tropical regions. It may serve as a preliminary step to predefine viable WECs for later, more detailed analyses, as described below. 


\subsection{Quantitative Analysis to Select Suitable WECs at Different Tropical Locations}

In order to determine which system would be suitable for a particular geographical area, the WEC devices available on the market were analyzed by Rusu and Onea [38]. They performed an estimation of the power output from specific devices in several locations worldwide, see Figure 2 (W1-W11). Ten devices were analyzed at these locations, including five point absorbers (PA), three wave-activated bodies (WAB), and two overtopping (OV) devices of different characteristics. Table 3 summarizes the main characteristics of these devices, which were classified into two categories according to their power output rating; matrix of WECs below $1000 \mathrm{~kW}$ and those above $2500 \mathrm{~kW}$. It is important to consider that these values were used for preliminary estimations at the time. Some of the devices are still under development and the given rated power data might vary due to possible technological changes in future manufacture. Despite this, the results serve as example for selecting suitable WECs for operation in tropical regions.

Table 3. Summary of the classification of WECs as a function of their corresponding rated power.

\begin{tabular}{ccccc}
\hline Type of WEC & $\begin{array}{c}\text { Principle of } \\
\text { Operation }\end{array}$ & Prototype Name & Dimensions (m) & Rated Power (kW) \\
\hline WECs & WAB & Pelamis & 150 & 750 \\
rated & PA & WaveBob & 20 & 1000 \\
below & PA & Ceto & 7 & 260 \\
$\mathbf{1 0 0 0} \mathbf{k W}$ & PA & OeabasedAB & 3 & 15 \\
& OV & OeaPoantec & 52 & 500 \\
\hline WECs & WAB & WaveStar & 76.75 & 2709 \\
Rated & WAB & PPC (Pontoon Power & 80 & 750 \\
Above & PA & Converter) & 50 & 2880 \\
$\mathbf{2 5 0 0} \mathbf{~ k W}$ & PA & OE (Ocean Energy Buoy) & Not available & 5900 \\
& OV & WaveDragon & \\
\hline
\end{tabular}

WAB (Wave-Activated Body), PA (Point Absorber), OV (Overtopping)

Figure 3 shows the theoretical power output of the devices described in Table 3 for the sites shown in Figure 2 (W1-W11). The power output of each device at a particular location was estimated by combining the available power matrices of the WECs with the bivariate distribution $\left(\mathrm{H}_{s} v \mathrm{vs} \mathrm{T}_{\mathrm{e}}\right.$, where $\mathrm{H}_{\mathrm{s}}$ is the significant wave and $\mathrm{T}_{\mathrm{e}}$ the mean wave period) obtained for each location for a 15-year time period (see [38]).

Figure 3a shows the results for the devices with power rated below $1000 \mathrm{~kW}$. A wave-activated body (WAB), three point absorbers (PA), and an overtopping device (OV) were compared. Notice that the expected power output of each device varies for each location (points W1 to W11). The overtopping device has the highest power output values for W3, W4, W6, W7, W9, and W11, whereas for the other sites, the point absorber devices provide most power. The PA (Sea-based AB) device has the lowest power output of all the devices, although this may be related to the low power rating and the size of this device, which suggests that such a device should be deployed in an array to obtain power at a larger scale.

Figure $3 \mathrm{~b}$ shows the power output for the WECs rated over $2500 \mathrm{~kW}$. In this case, the overtopping device has the highest power output at almost all of the locations, except for W11 where the PA (OE) device has the highest power output. The power outputs of the other devices were very similar one to another, although the WAB (SeaPower) and the PA (PPC) have the highest power outputs.

The results shown in Figure 3 do not offer a definitive selection of WECs for these locations. Other factors that should be considered include the size of the device, the convenience of operation conditions (e.g., adequate depth), the efficiency of the energy conversion system, and the reliability of the data used to estimate the wave conditions of the sites. These factors require further research. 


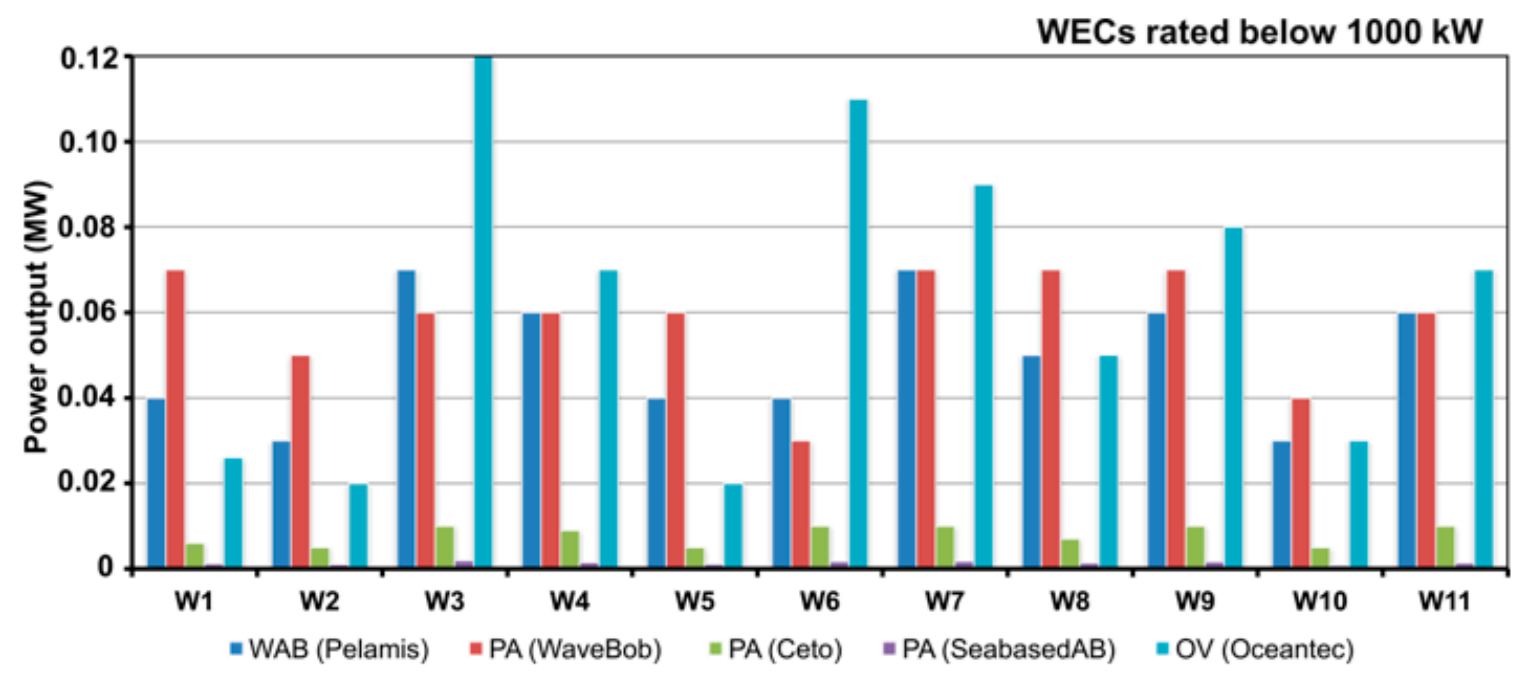

(a)

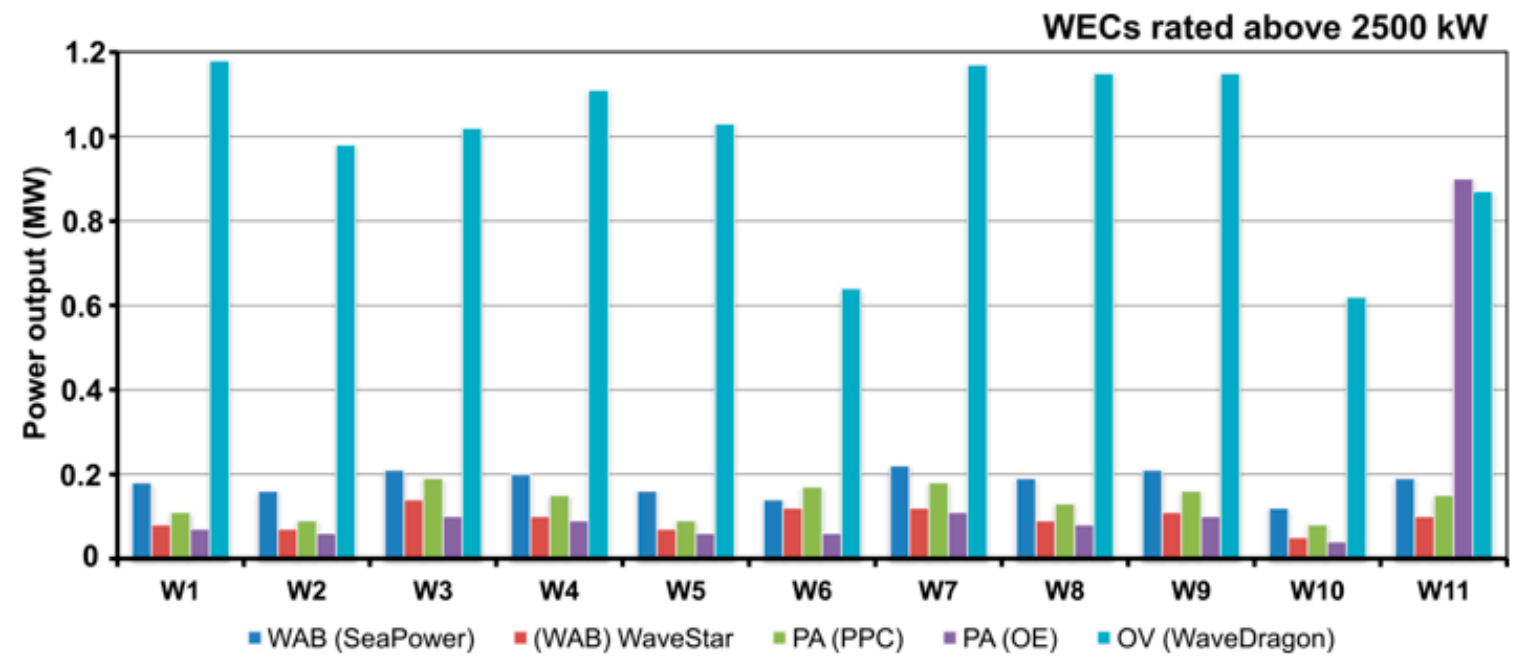

(b)

Figure 3. Theoretical power output (in MW) of various WECs for 11 locations. (a) WECs rated below $1000 \mathrm{~kW}$ in their power matrix. (b) WECs rated above $2500 \mathrm{~kW}$ in their power matrix.

\section{Technical Challenges for Wave Energy Harvesting}

The wave energy sector is currently at a stage in which numerous prototypes have been designed to extract energy in different wave climates around the world [38]. As yet, there is a lack of data on long-term reliability and on the commercial viability of large-scale energy production from these devices. OES [55] states that development activities to improve ocean energy technologies follow two key themes: (1) Identifying the best technologies from the current range, and (2) reducing the cost of the best devices, whilst enhancing their reliability and performance. While OES believes that the initial stages of ocean energy production will be expensive compared to existing electricity generation (coal, gas, oil, and nuclear), this cost difference is typical for new technologies. In general, the cost reduction pathways will be similar to those seen in wind and solar energy; as the technologies advance and become more efficient and their designs mature, they will be manufactured more cheaply [4]. The numerous types of devices for wave energy extraction require different development activities and collaboration between developers of competing devices in the design of common components can lower costs. The main challenges facing wave energy harvesting are similar to those that faced wind farms: Costs that cannot be competitive with existing forms of energy generation, grid connection, engagement of a WEC supply chain, and the problems arising from operating in hostile marine environments. 
The most urgent challenges for the extraction of wave energy can be separated into technical issues concerning the devices, including the WEC technology itself, as well as its implementation (placement, operation, maintenance, and removal), and social and ecological issues, where the challenges are determining the key points in tropical conditions that must be protected (Figure 4). In this section, the technical issues related to the WECs will be addressed.

\section{Challenges for wave energy extraction in tropical regions}

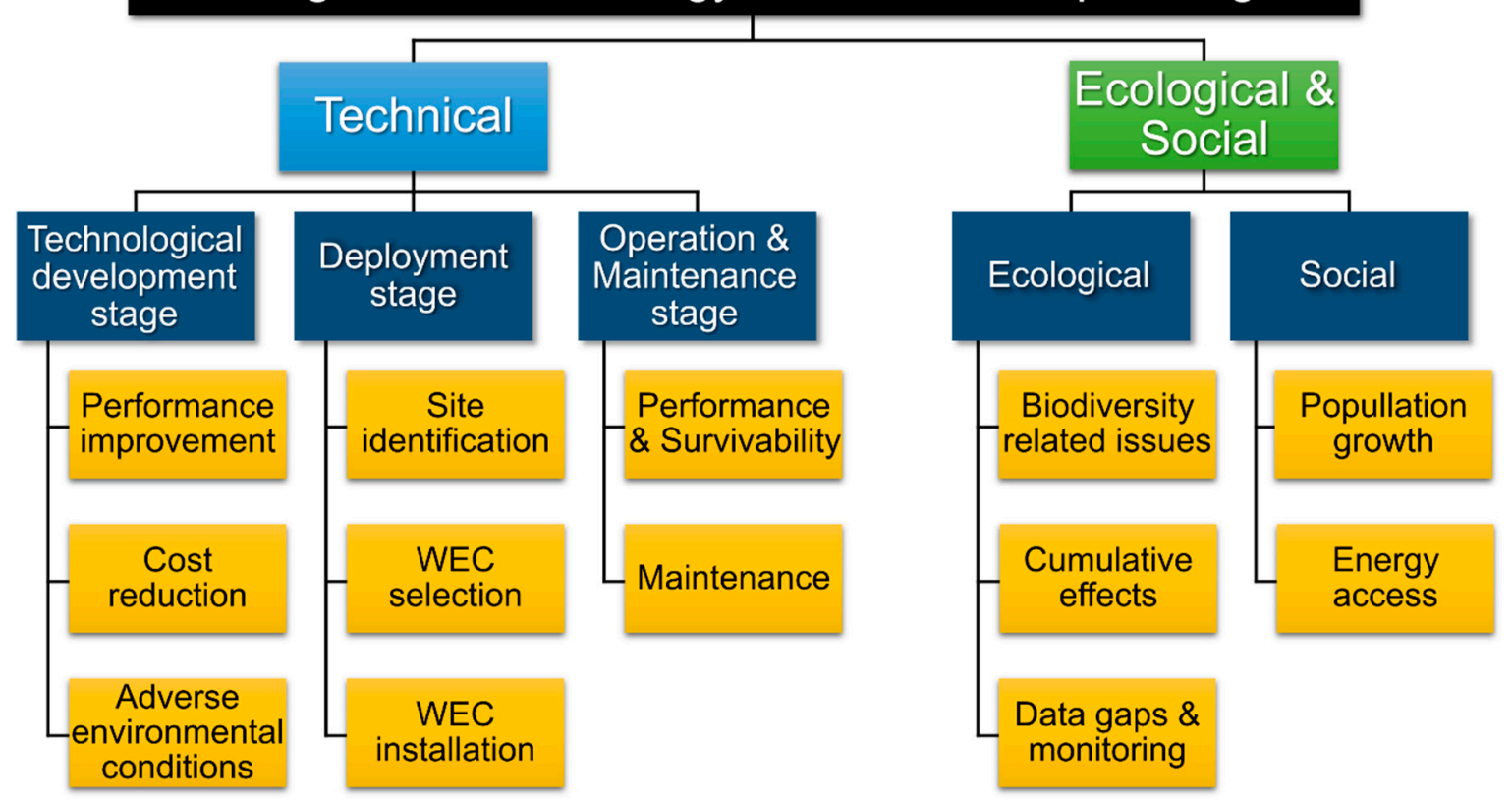

Figure 4. Challenges to be overcome in wave energy extraction projects in tropical regions.

\subsection{Technological Development Stage}

The operation of any device in an ocean environment is more complicated than those based on the ground. In the case of WECs, which interact with the waves the challenges are even more pronounced [4]. At present, there are more than 100 pilot and demonstration projects in existence, but only a few are operating full-time [12], and only a handful of technologies are close to commercialization [56]. Worldwide, efforts are focused on the improvement of WEC performance and cost reduction of WECs.

\subsubsection{Performance Improvement}

One of the most challenging issues in wave energy harvesting is the transformation of the irregular waves into a smooth electrical output, acceptable to the electricity grid, requiring some type of energy storage system or a means of reactive compensation. Not only do the WECs have to adapt to changes in wave height and period, they must also be able to align themselves on the wave fronts [57]. The WECs are made up of a number of components: (1) The structure and the prime mover that captures the wave energy, (2) the foundation or mooring, which keeps the structure and prime mover in place, (3) the power take-off (PTO) system, by which mechanical energy is converted into electrical energy, and (4) the control systems which safeguard and optimize performance in operation [58].

The general lines of current research and development focus on improving the components of the devices to make them more resistant to storms, to increase the amount of energy extraction possible, and on the deployment of groups of devices. Within technological improvements are the performance of the devices, their subsystems and components, methods for cost reduction, and means of facing adverse environmental conditions. As most WECs work with wave heights of over $2 \mathrm{~m}$ and associated periods of over $4 \mathrm{~s}$ [59], and these wave conditions do not occur in the tropics, there is a need to tune the devices to local wave conditions or develop new devices for better efficiency. 
Many devices have already undergone sea trials, but research is still needed on improving the lifespan of the devices, making the materials they are made of more resistant, etc. Improved installation and recovery techniques affect these areas, as does enhancing the operability and access for servicing, which reduces mean repair times. In general, all metallic materials exposed to seawater become corroded. In tropical coastal zones the high temperatures, humidity, and salinities mean that corrosion is an even more major problem.

\subsubsection{Cost Reduction}

Cost reduction is perhaps the most critical element for improvement, to ensure that ocean energy becomes competitive. With the large number of WECs on the market, there has been no convergence of wave conversion technology. Both the OES and IRENA (International Renewable Energy Agency) agree that as technologies advance and become more efficient, they can be manufactured at scale. Rusu and Onea [60] stated that expected improvements in the next generation of wave technology could reduce the costs of power take-off by $22 \%$, of installation by $18 \%$, and of operation and maintenance by $17 \%$, while costs in foundations and mooring, and grid connection could fall by $6 \%$ and $5 \%$, respectively. Another promising option to cut costs is by WECs sharing the infrastructure of existing offshore wind parks $[56,60]$.

\subsubsection{Adverse Environmental Conditions}

WEC devices must be able to withstand extreme conditions, which leads to difficult and costly maintenance operations as well as expensive moorings [58]. In tropical zones, these environmental loads are even greater, associated with high temperatures and episodic events, such as intense cyclones (hurricanes or typhoons). These cyclones present great wave heights, as well as great wave and wind speeds. To resist cyclone forces, WECs must have some type of mechanism that allows them to withstand cyclones or to have parts that are inexpensive and easy to replace. Another possibility is that these devices can be submersible or can be towed to a protected area while the storm passes. WEC anchoring must be strong enough to resist the currents that may be generated during a cyclone, so as not to lose the device completely. The possible need for recovery of the equipment, after a cyclone, should also be included in planning.

\subsection{Deployment Stage}

\subsubsection{Identification of Sites}

The National Research Council [61] and Laws and Epps [62] suggest that the selection of suitable places for wave energy extraction in tropical regions should be performed through theoretical and technical assessments of resources, i.e., estimating gross power with available or simulated data. Once the preliminary identification of potential sites is done, more specific evaluations should examine the prospective technologies (i.e., technical assessments). In tropical regions, biodiversity is more abundant than in other regions of the world, so the ecological restrictions should also be abundant. Finally, techno-economic analyses of the regions should be performed in order to identify the most profitable sites for investment [16].

\subsubsection{WEC Selection}

Two alternatives are proposed for the selection of WEC devices from those available. The first requires ready-made prototypes to attain operational conditions, at maximum efficiency for the prospective site, and, secondly, existing WECs are adapted, or specially tailored devices used. For this option, quality control during the design process is required. Validation and operational testing are also needed, for which guidelines such as the Technology Readiness Levels should be followed [63]. 


\subsubsection{Installation of WECs}

The conditions of the substrata, environmental, and logistic issues could all affect installation activities. Detailed studies related to the geomorphologic and oceanographic conditions of the potential location for deployment are necessary to predict changes in the substrata strength. Problems can be overcome by completely fixing the WECs to the ground (i.e., fixed devices) or by anchoring them at specific points (i.e., moored-floating devices). Research is needed to devise installation procedures, which comply with international regulations related to the deployment of marine devices. As many tropical countries do not have adequate facilities to deploy devices in the field, another important point to consider is the logistic effort required to acquire additional or Supplementary Materials, equipment, or machinery for installation; it is crucial to consider sites close to coastal, naval, or offshore installations with infrastructure for storage, supply, and transportation of components.

\subsection{Operation and Maintenance Stage}

The operation and maintenance stages of WEC projects refer to their performance and survivability. Frequent inspections (i.e., preventive maintenance) are required to avoid corrective maintenance of the devices.

\subsubsection{Performance and Survivability}

The reliability of operations can be tested in controlled environments, characterizing the way a device behaves in regular, or irregular, waves. However, in real conditions, prototype devices might present unexpected behavior in the harsh environment [64]. As with other naval and offshore structures, such as ships or floating platforms, WECs might experience extreme events, such as slamming (i.e., a significant wave impact on the external device structure, [65]) or high accelerations [66], which might damage the structure or its electrical or mechanical components. These challenges have to be addressed via technical research in order to identify the failure modes of the devices and to improve their dynamic behavior in extreme wave conditions, including hydro-elastic effects.

\subsubsection{Maintenance}

Ideally, preventive maintenance instead of the more expensive corrective maintenance would be carried out. This may also prevent environmental damage. As most WECs are marine structures with moving parts such as articulations or cables, structural fatigue is an important concern. Periodic inspections are needed to verify the conditions of electrical and mechanical components, as well as to ensure the lubrication of moving components, thus avoiding attrition between them. The high temperatures of tropical regions may accelerate the spread of aquatic microorganisms in the devices, so biofouling-induced degradation of components is a very real threat [67].

\section{Environmental and Social Challenges for Wave Energy Harvesting}

Since WECs vary so much in their technologies and dimensions, and site locations vary in relation to the water column and the distance from the coast, it is difficult to make generalizations about the potential negative effects of wave power devices [68]. However, tropical countries share ecological and social characteristics such as high biodiversity and uneven economic development [69], characteristics that have to be taken seriously by the marine energy industry.

Avoiding or minimizing the potential negative impacts of WECs in the Tropics is a major challenge, due to the high diversity of birds, fish, turtles, and corals and the fact that this biodiversity is already threatened. The deployment of WEC projects could cause cumulative impacts and compromise the health and resilience of marine and coastal ecosystems [70,71]. As coastal communities in tropical zones are very reliant on the goods and services provided by these ecosystems, such as fisheries and beach protection, any change to these ecosystems could have serious social consequences [72]. On the other 
hand, the installation of WECs could generate environmental benefits, such as the implementation of fishing exclusion zones, where depleted fish populations could recover [73].

In addition to the ecological and social complexity, heterogeneous environmental consenting processes and the lack of long-term data could jeopardize the support for marine energy projects in tropical countries. For example, the willingness to pay for marine energy deployment is strongly linked to the expectation to move towards a sustainable energy supply and lessen the environmental footprint associated with the energy sector. However, the lack of long-term data prevents the establishment of a baseline that would be key for a comprehensive Environmental Impact Assessment (EIA) for any project. There is, therefore, an urgent need to identify potential areas for energy production and to prioritize efforts and resources as well as to design monitoring protocols [74].

\subsection{Ecological Challenges}

\subsubsection{Megadiversity of Coastal Tropical Zones}

The environmental challenges faced by the marine energy industry are exacerbated when potential sites are located in or near areas of conservation. These overlaps occur all over the world but are more common in the Tropics. The World Conservation Monitoring Centre of the UN Environment Program (UNEP-WCMC) lists the 17 countries considered as megadiverse; they are all either totally or partially in the tropical zone.

The spatial patterns of fauna diversity vary throughout the Tropics; coastal birds are more diverse in The Americas, while marine fish are more diverse in Asia and Oceania. These complex biodiversity patterns add further difficulties to the task of minimizing negative marine energy impacts as can be seen in Figure 5a-d ([75]).

The potential environmental effects of WECs have been investigated by several authors [24,76,77], showing that the main environmental receptors of WEC impacts are physical (water quality and hydro sedimentary dynamics) and biological (birds, fish, mammals, and turtles). It has also been pointed out that the intensity and duration of these impacts depend on the receptor, device, and project phase [78]).

Birds, fish, mammals, and turtles are some of the highly diverse groups that could be affected by WECs installed in the Tropics (Figure 6). Fauna that swim near the surface is prone to collide with underwater infrastructure and become entangled in suspended cables and moorings. This can cause injuries that reduce swimming ability, disruption to feeding, and possibly lead to death. These effects depend on the body size and flexibility of the fauna and its feeding behavior, as well as its ability to detect the risk [24]. In addition, underwater noise, vibrations, and electromagnetic emissions have also been highlighted as major concerns, as they can disrupt the communication, feeding, and navigation of many marine species [79]. Even though potential impacts of underwater noise are widely recognized, the uncertainty over the variability in baseline noise levels makes it difficult to establish limits [80]. 


\section{a) All species}

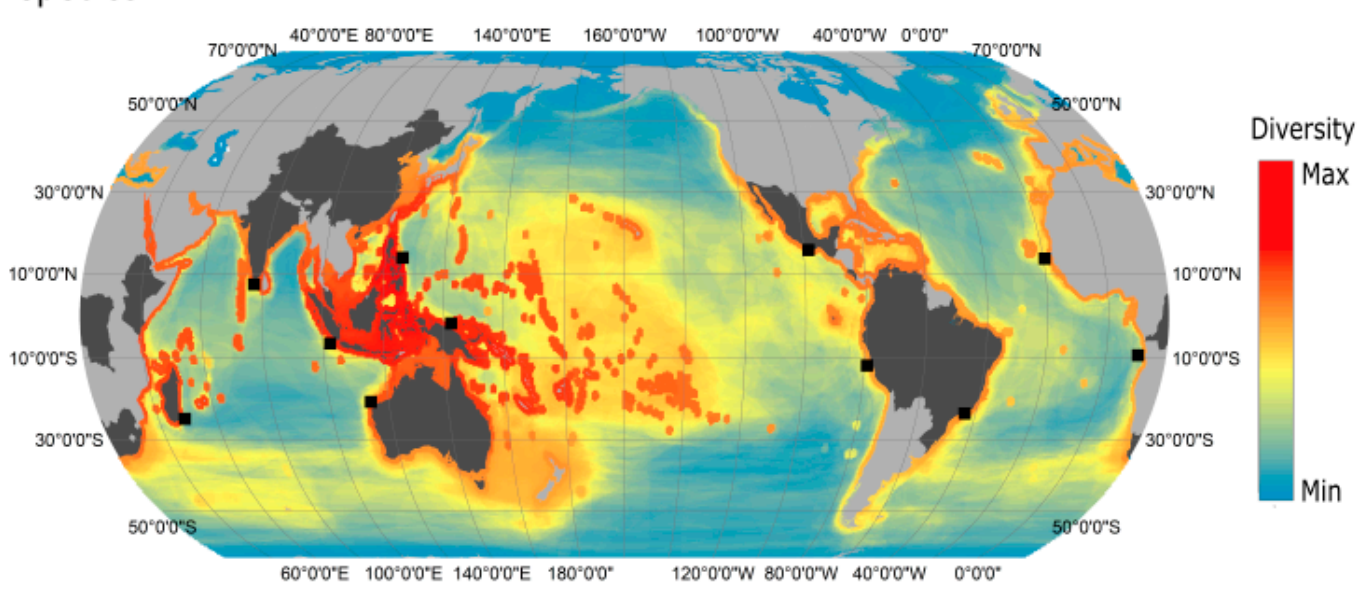

b) Seabirds

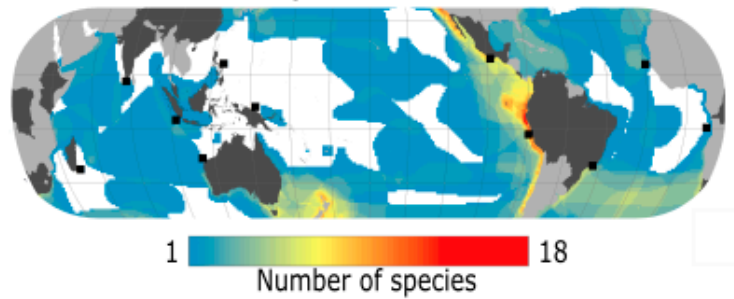

d) Marine fish

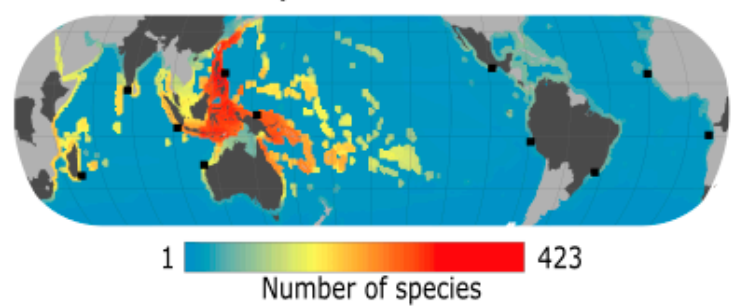

c) Marine mammals

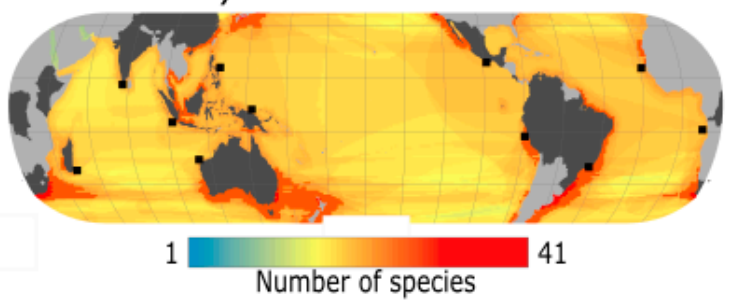

e) Corals

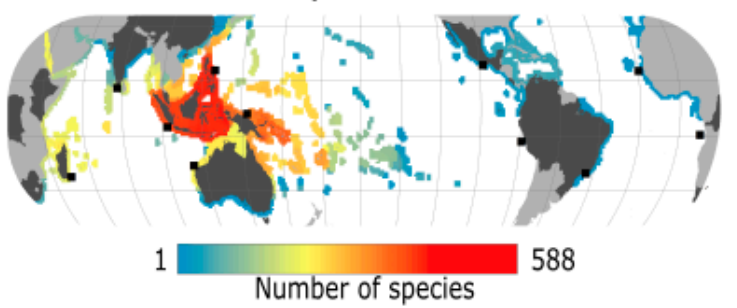

Figure 5. Marine diversity in the Tropics. (a) All species, (b) seabirds; (c) marine mammals; (d) marine fish; (e) corals. Black squares: Potential sites for wave energy conversion plants, see Figure 2.

The potential effects vary depending on the phase of the WEC project. For example, during deployment, the impacts are related to water and sediment pollution, derived from chemical leaching and spills; physical damage of local ecosystems in the course of installation of support structures (including mooring lines); and changes in animal behavior such as avoidance or attraction to the project area [78]. In turn, impacts during operation and maintenance phases are possibly related to underwater noise and electromagnetic field emissions, which can produce changes in animal behavior and distribution. In addition, WECs have been associated with long-term perturbations to nearfield ecosystems derived from changing natural hydro sedimentary flow patterns around the devices, which can produce coastal erosion [76].

Perturbation of ecosystems due to marine energy projects is therefore a global conservation concern and design strategies to avoid or mitigate them are among the primary challenges facing marine renewables industry in the zone. 


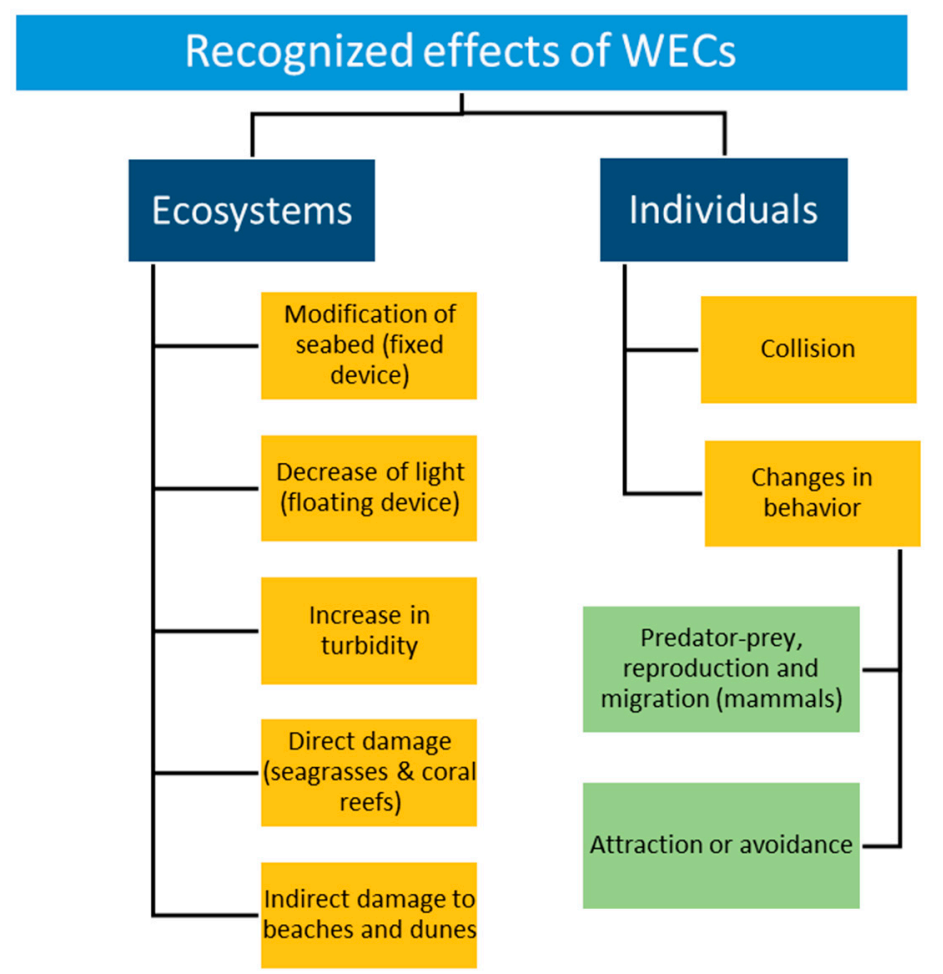

Figure 6. Effects on individuals and coastal ecosystems of WECs.

\subsubsection{Data Gap and Monitoring Efforts}

According to the UNEP, the most common and useful environmental management tool to evaluate the impacts of physical developments is EIA. It is a key strategy to accomplish the 2030 Agenda for Sustainable Development [81]. Although almost all countries in the tropical zone have environmental regulations, the systematic assessment of environmental impacts is less common and the implementation of internationally recognized methods has been slow. Hence, EIA process for WEC projects is still undetermined in many countries.

EIA of WEC projects in tropical areas is particularly important in view of the high regional biodiversity and known risks of marine renewable energy devices. However, the EIA processes depend on elements such as legal support, public participation, and accessible quality data. The absence of long-term data is an obstacle to fixing a baseline and means that inaccurate and unreliable assessments may be made at all points of the EIA process, from identifying sites to WEC design and even decommissioning.

\subsubsection{Cumulative Impacts}

Tropical coastal zones face increasing levels of stress from several factors such as fisheries, aquaculture, marine debris, oil extraction, urbanization, and climate change. The combined effects of these activities affect ecosystem health, resistance, and resilience. WECs could further threaten the ecosystems and human communities. As devices may be deployed in places with residual impacts from prior or ongoing activities, a WEC could trigger a greater net cumulative impact than the sum of each individual effect. The minimizing of these synergistic impacts of WECs must be avoided.

\subsection{Social Challenges}

The provision of alternative sources of energy, such as marine energy, is stated in the seventh goal of the United Nations sustainable development agenda for 2030 named "Affordable and Clean Energy" [82]. Marine renewable energies (MRE) have the potential to improve access to energy for the growing population of the Tropics. 
More than two-thirds of the world population living in extreme poverty live in the Tropics [83]. Moreover, the vulnerability of these populations to extreme events is growing, as more people move to the coast. The degree of perturbation of natural ecosystems such as beaches, coral reefs, and mangrove areas is increasing rapidly [84].

Although significant progress has been made in the last three decades, there is still a widespread low human development index (HDI is a measure that combines life expectancy, education, and per capita income [85]) in tropical zones worldwide. Over the last 30 years, the number of people in South East Asia and Central America living in extreme poverty fell by around 60\%. In South Asia and South America, HDI values also improved significantly. However, poverty in Central and Southern Africa as well as in the Caribbean has actually increased [86].

Coastal zones in tropical countries are some of the most populated areas in the world, with population increases forecast for the future [69]. Table 4 shows the population living in tropical countries with a coastline for 2010 and 2100 and the proportion of that population living in low-lying areas along the coast (less than 10 meters above sea level). South Asia was by far the most populated region in 2010. While the projected population growth to 2100 is highest in African countries, Oceania has the highest proportion of the population living in low-elevation areas in coastal zones (LECZ) (25\%), followed by Southeast Asia and South America [87].

Table 4. Demographic trends and population living in low-elevation areas in coastal zones (LECZ).

\begin{tabular}{ccccc}
\hline Region & Population 2010 & Population 2100 & $\begin{array}{c}\text { Population \& } \\
\text { Extreme Poverty }\end{array}$ & \% LECZ 2010 \\
\hline Central \& Southern Africa & $24,337,645$ & $56,629,470$ & $54 \%$ & $9 \%$ \\
Northern Africa & $5,651,315$ & $14,048,546$ & $29 \%$ & $16 \%$ \\
South Asia & $1,241,491,960$ & $1,708,470,144$ & $33 \%$ & $7 \%$ \\
Southeast Asia & $761,415,061$ & $442,509,998$ & $14 \%$ & $22 \%$ \\
Caribbean & $36,752,994$ & $46,309,629$ & $28 \%$ & $13 \%$ \\
Mexico \& Central America & $120,925,041$ & $198,374,035$ & $3 \%$ & $21 \%$ \\
South America & $288,895,347$ & $462,802,736$ & $6 \%$ & $12 \%$ \\
\hline Continent & & & & $15 \%$ \\
Africa & $29,988,960$ & $70,678,016$ & - & $14 \%$ \\
Asia & $2,002,907,021$ & $2,150,980,142$ & - & $26 \%$ \\
\hline Oceania & $446,573,382$ & $707,486,400$ & - & \\
\hline
\end{tabular}

Rapid population growth and the global trend of moving to coastal areas could worsen the poverty situation in the Tropics and increase the vulnerability of coastal populations there to extreme events.

The increase in poverty levels can also trigger social conflicts and poor governance, impeding local investment in new technologies, such as marine energy. In fact, most of the world's infrastructure deficit is in the Tropics [83]). The causes of this deficit are manifold and can be triggered by environmental conditions, extreme events, and limited investment in science and technology. Nonetheless, tropical countries have opportunities to develop more efficient, decentralized, renewable forms of energy generation.

The 2030 Agenda for Sustainable Development lists one of its goals as ensuring access to affordable, reliable, sustainable and modern energy for all as previously mentioned [82]. In consequence, increasing the use of renewable energies such as WECs is encouraged. Increasing clean energy generation can help reduce morbidity and premature mortality from illnesses attributable to household air pollution, produced by the use of solid fuel for cooking, and outdoor pollution, related to industry and transport [86]. 


\section{The Mexican Strategy for MRE}

The Mexican government has made important changes in the energy laws since 2013 to encourage renewable energy development. One of the objectives of these reforms is to link the public sector with academic research, in order to develop technology specifically for Mexican energy sources. The Mexican Centres for Innovation in Renewable Energies (CEMIE) were thus created, covering all renewable energies.

CEMIE-Oceano began working in January 2017. It is formed by researchers from more than 40 public and private institutions whose aims are to: (1) Develop technology that allows efficient use the ocean energy sources (waves, currents, thermal, and saline gradients); (2) develop new materials and ways to store and link generating devices to the national electricity grid; (3) train human resources, generate new companies, and disseminate the knowledge acquired to society.

CEMIE-Oceano is working on much more than simply wave energy harvesting. The Cozumel channel is being monitored and studied as a feasible site for the exploitation of ocean current energy. Laboratory models for electricity generation from salinity gradients have been produced and tested. OTEC plants are being designed in Acapulco and Cozumel.

CEMIE-Oceano is currently evaluating energy availability from waves in deep waters, using numerical models, and re-analysis data. From these results, the spatial and temporal availability of the energy is being assessed. The next step is to perform downscaling of the data to take into account the geomorphological influence on the coastal zone and thus determine the wave potential for shallow waters in specific places, particularly in the Mexican tropical zone.

On the other hand, the Center is also working on the developing devices optimized for Mexican waves, e.g., the Blow-Jet [88] and a floating mono-buoy. A magneto hydrodynamic energy generator model has also been built and tested.

CEMIE-Oceano is also working on a new set of superhydrophobic and nanostructured ceramic and polymeric coatings as well as a nitriding process, which avoids corrosion of steel, and has been successfully developed and tested. In addition, strategies for energy storage and micro- and intelligent grids are being developed.

In the socio-environmental field, the CEMIE-O has generated information on the structure, composition and functioning of ecosystems and coastal and marine species in order to determine the potential impacts of the installation of energy plants in the ocean. Inventories of flora and fauna at the potential exploitation sites have been made.

\section{Conclusions}

Wave energy can contribute to resolving a number of social problems common to tropical countries. However, it is still a long way from being a competitive industry in developing countries in the Tropics, due to technical, environmental, and social issues. In this paper, a diagnosis of challenges related to the use of energy from waves, common to tropical areas, was presented.

The results obtained regarding power availability can strongly modify the previous estimations of levelized cost of energy (LCOE) on tropical regions, specifically those related to low power harnessing and conversion. If the expected cost is lowered, the viability of developing a wave energy electricity industry in tropical regions would be, obviously, enhanced.

Regarding technical challenges, the need for local or adapted technology was identified. Suitable wave energy conversion devices are needed to efficiently convert available wave energy, taking into consideration local marine climates. Research and development in materials resistant to the warm saline waters and the high nutrient levels of tropical zones is also required for the design, maintenance, and survivability of the devices. In turn, devices designed to withstand extreme meteorological events common in tropical areas are also required, if there is to be a viable industry. A novel computation of the available energy expressed as yearly power percentage was detailed, to contribute to device design, energy plant planning, and marketing wave energy, 
Environmental challenges are mostly related to the megadiversity found in the Tropics. Environmental impact assessments should be undertaken in detail, considering local conditions. Alternative strategies and proposals are needed to ensure sustainability in areas where the exceptional natural resources cannot be threatened. Another challenge is the development of permanent monitoring programs for both physical and biological environments in order to gather data regarding the functioning, responses, and resilience of marine ecosystems, thus limiting the dimensions, number, and operational principles of the devices and the energy that can be extracted.

In terms of social necessities, it is important that WECs are deployed close to centers of energy demand to reduce costs and enhance their efficiency. In the future, the costs of production and delivery to final users in isolated communities should become competitive to traditional means of energy generation. With the implementation of these technologies in the Tropics, social problems can be addressed and must therefore be the motivation for tropical countries to fund research into wave energy conversion.

Mexico, in particular, the CEMIE-Oceano is carrying out research and development for the deployment of WECs that are compatible with local waves and resistant to climate demands, as well as developing coatings that reduce corrosion. It is also conducting studies of environmental and social monitoring, to lay the foundations for the exploitation of wave energy in a sustainable manner.

Supplementary Materials: Complementary material can be found in the Mendeley Dataset repository: http: //dx.doi.org/10.17632/dv8fz9cvsj.1.

Author Contributions: A.F. contributed with the methodology, writing, review and editing and data analysis. J.V.H.-F. worked in data analysis, investigation and writing. D.L. helped investigating the environmental and social challenges and visualization. E.M. gave the conceptualization and main ideas, supervision and funding acquisition. G.P. worked in resuming and integrating the technical challenges. M.R. contributed with data preparation and visualization. R.S. helped with funding acquisition, review and editing and general supervision.

Funding: This research was partially funded by Fondo CONACYT-SENER/Sustentabilidad Energética through the Centro Mexicano de Inovación en Energías del Océano (CEMIE-Océano), grant number 249795.

Acknowledgments: J.V.H.-F. wishes to thank the support provided by the DGAPA-UNAM postdoctoral fellowship.

Conflicts of Interest: The authors declare no conflict of interest.

\section{Abbreviations}

CEMIE-Oceano

Hs

HDI

IRENA

LECZ

MRE

OE

OES

OWC

OV

PA

PPC

PTO

$T_{01}$

UNEP

W

WAB

WEC
Centre for Innovation in Renewable Energy from the Ocean

Significant wave height

Human development index

International Renewable Energy Agency

Low elevation areas in coastal zones

Marine renewable energies

Ocean Energy Buoy (device name)

Ocean Energy Systems of the International Energy Agency

Oscillating water column

Overtopping (principle of operation of a WEC)

Point absorber (principle of operation of a WEC)

Pontoon Power Converter (device name)

Power take-off from a device

Energetic wave period

United Nations Environmental Program

Watts, (MW megawatts, kW, kilowatts)

Wave activated body (principle of operation of a WEC)

wave energy converter 


\section{References}

1. Mustapa, M.A.; Yaakob, O.B.; Ahmed, Y.M.; Rheem, C.K.; Koh, K.K.; Adnan, F.A. Wave energy device and breakwater integration: A review. Renew. Sustain. Energy Rev. 2017, 77, 43-58. [CrossRef]

2. Bray, J.W.; Fair, R.; Haran, K. Wind and ocean power generators. IEEE Trans. Appl. Supercond. 2014, 24, 5200407. [CrossRef]

3. Falnes, J.; Lillebekken, P.M. Budal's latching-controlled-buoy type wave-power plant. In Proceedings of the 5th European Wave Energy Conference, Cork, Ireland, 17-20 September 2003; pp. 233-244.

4. Aderinto, T.; Li, H. Ocean wave energy converters: Status and challenges. Energies 2018, 11, 1250. [CrossRef]

5. EMEC (The European Marine Energy Centre) Marine Energy. Available online: http://www.emec.org.uk/ marine-energy/ (accessed on 28 February 2019).

6. Bahaj, A.S. Generating electricity from the oceans. Renew. Sustain. Energy Rev. 2011, 15, 3399-3416. [CrossRef]

7. Vega, L.A. Ocean thermal energy conversion primer. Mar. Technol. Soc. J. 2009, 36, 25-35. [CrossRef]

8. Uehara, H.; Miyara, A.; Ikegami, Y.; Nakaoka, T. Performance analysis of an OTEC plant and a desalination plant using an integrated hybrid cycle. J. Sol. Energy Eng. 1996, 118, 115-122. [CrossRef]

9. Vega, L.A.; Michaelis, D. First generation 50 MW OTEC plantship for the production of electricity and desalinated water. In Proceedings of the Offshore Technology Conference, Houston, TX, USA, 3-6 May 2010.

10. Jia, Z.; Wang, B.; Song, S.; Fan, Y. Blue energy: Current technologies for sustainable power generation from water salinity gradient. Renew. Sustain. Energy Rev. 2014, 31, 91-100. [CrossRef]

11. Stancanelli, L.M.; Musumeci, R.E.; Cavallaro, L.; Foti, E. A small scale pressure retarded osmosis power plant: Dynamics of the brackish effluent discharge along the coast. Ocean Eng. 2017, 130, 417-428. [CrossRef]

12. OES Web SIG. Offshore-Installations Worldwide. Available online: https://www.ocean-energy-systems.org/ ocean-energy-in-the-world/gis-map/ (accessed on 14 December 2018).

13. Val, A.L.; De Almeida-Val, V.M.F.; Randall, D.J. Tropical environment. In The Physiology of Tropical Fishes; Elsevier: Amsterdam, The Netherlands, 2006; pp. 1-45.

14. Purba, N.P.; Kelvin, J.; Sandro, R.; Gibran, S.; Permata, R.A.I.; Maulida, F.; Martasuganda, M.K. Suitable locations of Ocean Renewable Energy (ORE) in Indonesia region-GIS approached. Energy Procedia 2015, 65, 230-238. [CrossRef]

15. Sandro, R.; Arnudin; Tussadiah, A.; Utamy, R.M.; Pridina, N.; Afifah, L.N. Study of wind, tidal wave and current potential in sunda strait as an alternative energy. Energy Procedia 2014, 47, 242-249. [CrossRef]

16. Quitoras, M.R.D.; Abundo, M.L.S.; Danao, L.A.M. A techno-economic assessment of wave energy resources in the Philippines. Renew. Sustain. Energy Rev. 2018, 88, 68-81. [CrossRef]

17. Sannasiraj, S.A.; Sundar, V. Assessment of wave energy potential and its harvesting approach along the Indian coast. Renew. Energy 2016, 99, 398-409. [CrossRef]

18. Hemer, M.A.; Manasseh, R.; McInnes, K.L.; Penesis, I.; Pitman, T. Perspectives on a way forward for ocean renewable energy in Australia. Renew. Energy 2018, 127, 733-745. [CrossRef]

19. SEA Sustainable Energy Solutions for South African Local Government: A Practical Guide. Cape Town: Sustainable Energy Africa. Available online: https://www.sustainable.org.za (accessed on 10 December 2018).

20. Joubert, J.R.; Niekerk, J.L. Van recent developments in wave energy along the coast of southern Africa. In Proceedings of the 8th European Wave and Tidal Energy Conference, Uppsala, Sweden, 7-10 September 2009; pp. 1096-1100.

21. Osorio, A.F.; Ortega, S.; Arango-Aramburo, S. Assessment of the marine power potential in Colombia. Renew. Sustain. Energy Rev. 2016, 53, 966-977. [CrossRef]

22. Hernández-Fontes, J.V.; Felix, A.; Mendoza, E.; Rodríguez Cueto, Y.S. On the marine energy resources of Mexico. J. Mar. Sci. Technol. 2019, in press.

23. Gepts, P. Tropical environments, biodiversity, and the origin of crops. In Genomics of Tropical Crop Plants; Springer: Cham, Switzerland, 2008.

24. Riefolo, L.; Lanfredi, C.; Azzellino, A.; Vicinanza, D. Environmental impact assessment of wave energy converters: A review. In Proceedings of the International Conference on Applied Coastal Research SCACR, Florence, Italy, 28 September-1 October 2015.

25. Margheritini, L.; Hansen, A.M.; Frigaard, P. A method for EIA scoping of wave energy converters-based on classification of the used technology. Environ. Impact Assess. Rev. 2012, 32, 33-44. [CrossRef] 
26. Andersen, K.; Chapman, A.; Hareide, N.R.; Folkestad, A.O.; Sparrevik, E.; Langhamer, O. Environmental monitoring at the maren wave power test site off the Island of Runde, Western Norway: Planning and design. In Proceedings of the 8th European Wave and Tidal Energy Conference, Uppsala, Sweden, 7-10 September 2009; pp. 1029-1038.

27. Cornett, A.M. A global wave energy resource assessment. Sea Technol. 2009, 50, 59-64.

28. Mork, G.; Barstow, S.; Kabuth, A.; Pontes, M.T. Assessing the global wave energy potential. In Proceedings of the 29th International Conference on Ocean, Offshore and Arctic Engineering, Shanghai, China, 6-11 June 2010; Volume 3, pp. 447-454.

29. Sánchez, A.S.; de Jong, P.; Torres, E.A. Wind, solar and waves' energy in the NE region of Brazil: Analysis of meteorological parameters related to the load curve of electric demand (In Portuguese). In Proceedings of the Conference CONEM 2012-7th Brazilian National Congress of Mechanical Engineering, São Luis, Brazil, 31 July-3 August 2012.

30. Zhang, D.; Li, W.; Lin, Y. Wave energy in China: Current status and perspectives. Renew. Energy 2009, 34, 2089-2092. [CrossRef]

31. Pillai, I.R.; Banerjee, R. Renewable energy in India: Status and potential. Energy 2009, 34, 970-980. [CrossRef]

32. Muzathik, A.M.; Nik, W.S.; Ibrahim, Z.; Samo, K.B. Wave energy potential of Peninsular Malaysia. J. Eng. Appl. Sci. 2010, 5, 11-23.

33. Muzathik, A.M.; Wan Nik, W.B.; Samo, K.B.; Ibrahim, M.Z. Ocean wave measurement and wave climate prediction of Peninsular Malaysia. J. Phys. Sci. 2011, 22, 77-92.

34. Aboobacker, V.M.; Shanas, P.R.; Alsaafani, M.A.; Albarakati, A.M.A. Wave energy resource assessment for Red Sea. Renew. Energy 2017, 114, 46-58. [CrossRef]

35. Bernardino, M.; Rusu, L.; Guedes Soares, C. Evaluation of the wave energy resources in the Cape Verde Islands. Renew. Energy 2017, 101, 316-326. [CrossRef]

36. Wang, Z.; Duan, C.; Dong, S. Long-term wind and wave energy resource assessment in the South China sea based on 30-year hindcast data. Ocean Eng. 2018, 163, 58-75. [CrossRef]

37. Kompor, W.; Ekkawatpanit, C.; Kositgittiwong, D. Assessment of ocean wave energy resource potential in Thailand. Ocean Coast. Manag. 2018, 160, 64-74. [CrossRef]

38. Rusu, L.; Onea, F. The performance of some state-of-the-art wave energy converters in locations with the worldwide highest wave power. Renew. Sustain. Energy Rev. 2017, 75, 1348-1362. [CrossRef]

39. Salter, S.H. Wave power. Nature 1974, 249, 720-724. [CrossRef]

40. Dee, D.P.; Uppala, S.M.; Simmons, A.J.; Berrisford, P.; Poli, P.; Kobayashi, S.; Andrae, U.; Balmaseda, M.A.; Balsamo, G.; Bauer, P.; et al. The ERA-Interim reanalysis: Configuration and performance of the data assimilation system. Q. J. R. Meteorol. Soc. 2011, 137, 553-597. [CrossRef]

41. Heller, V.; Chaplin, J.; Farley, F. Physical model tests of the anaconda wave energy converter. In Proceedings of the 1st IAHR European Congress, Edinburgh, UK, 4-6 May 2000; Volume 1, pp. 3-8.

42. Alamian, R.; Shafaghat, R.; Miri, S.J.; Yazdanshenas, N.; Shakeri, M. Evaluation of technologies for harvesting wave energy in Caspian Sea. Renew. Sustain. Energy Rev. 2014, 32, 468-476. [CrossRef]

43. López, I.; Andreu, J.; Ceballos, S.; De Alegría, I.M.; Kortabarria, I. Review of wave energy technologies and the necessary power-equipment. Renew. Sustain. Energy Rev. 2013, 27, 413-434. [CrossRef]

44. He, F.; Huang, Z.; Law, A.W.K. An experimental study of a floating breakwater with asymmetric pneumatic chambers for wave energy extraction. Appl. Energy 2013, 106, 222-231. [CrossRef]

45. Osanai, S.; Kondo, H.; Mizuno, Y.; Watabe, T. Faesibility tests of new pendular-type wave. In Proceedings of the 25th Conference on Coastal Engineering, Orlando, FL, USA, 2-6 September 1996; Edge, B.L., Ed.; American Society of Civil Engineers: Orlando, FL, USA, 1996; pp. 4591-4600.

46. Weinstein, A.; Fredrikson, G.; Claeson, L.; Jane, J.M.; Aquaenergy, P.; Nielsen, K.; Sand, M.; Rambbll, J. AquaBuOY-the offshore wave energy converter numerical modeling and optimization. In Proceedings of the Oceans 2003: Celebrating the Past ... Teaming Toward the Future, San Diego, CA, USA, 22-26 September 2003; pp. 1988-1995.

47. Polinder, H.; Damen, M.E.C.; Gardner, F. Design, modelling and test results of the AWS PM linear generator. Eur. Trans. Electr. Power 2005, 15, 245-256. [CrossRef]

48. Seymour, R.J. (Ed.) Ocean Energy Recovery: The State of the Art; American Society of Civil Engineers: New York, NY, USA, 1992; ISBN 978-0-87262-894-6. 
49. Brito-Melo, A.; Neuman, F.; Sarmento, A.J.N.A. Full-scale data assessment in OWC Pico plant. In Proceedings of the Seventeenth International Offshore and Polar Engineering Conference, Lisbon, Portugal, 1-6 July 2007.

50. Boccotti, P. On a new wave energy absorber. Ocean Eng. 2003, 30, 1191-1200. [CrossRef]

51. Kofoed, J.P.; Frigaard, P.; Friis-Madsen, E.; Sørensen, H.C. Prototype testing of the wave energy converter wave dragon. Renew. Energy 2006, 31, 181-189. [CrossRef]

52. Vicinanza, D.; Margheritini, L.; Kofoed, J.P.; Buccino, M. The SSG wave energy converter: Performance, status and recent developments. Energies 2012, 5, 193-226. [CrossRef]

53. Contestabile, P.; Iuppa, C.; Di Lauro, E.; Cavallaro, L.; Andersen, T.L.; Vicinanza, D. Wave loadings acting on innovative rubble mound breakwater for overtopping wave energy conversion. Coast. Eng. 2017, 122, 60-74. [CrossRef]

54. Alifdini, I.; Iskandar, N.A.P.; Nugraha, A.W.; Sugianto, D.N.; Wirasatriya, A.; Widodo, A.B. Analysis of ocean waves in 3 sites potential areas for renewable energy development in Indonesia. Ocean Eng. 2018, 165, $34-42$. [CrossRef]

55. Ocean Energy Systems (OES). An International Vision for Ocean Energy; Ocean Energy Systems: Lisbon, Portugal, 2017.

56. Ruud, K.; Frank, N. Wave energy technology brief. In Future Energy: Improved, Sustainable and Clean Options for our Planet; Elsevier: Amsterdam, The Netherlands, 2014; pp. 357-382.

57. Drew, B.; Plummer, A.R.; Sahinkaya, M.N. A review of wave energy converter technology. Proc. Inst. Mech. Eng. Part A J. Power Energy 2009, 223, 887-902. [CrossRef]

58. Titah-benbouzid, H.; Benbouzid, M.; Titah-benbouzid, H.; Benbouzid, M. Ocean wave energy extraction: Up-to-date technologies to cite this version: HAL Id: Hal-01120777 ocean wave energy extraction: Up-to-date technologies review and evaluation. Int. Rev. Electr. Eng. 2015, 10, 52-61.

59. Cahill, B.; Lewis, T. Wave energy resource characterization and the evaluation of potential Wave Farm sites. In Proceedings of the Oceans'11 MTS/IEEE KONA, Waikoloa, HI, USA, 19-22 September 2011.

60. Rusu, E.; Onea, F. A review of the technologies for wave energy extraction. Clean Energy 2018, 2, 10-19. [CrossRef]

61. National Research Council. An Evaluation of the U.S. Department of Energy's: Marine and Hydrokinetic Resource Assessments; The National Academies Press: Washington, DC, USA, 2013.

62. Laws, N.D.; Epps, B.P. Hydrokinetic energy conversion: Technology, research, and outlook. Renew. Sustain. Energy Rev. 2016, 57, 1245-1259. [CrossRef]

63. De Rose, A.; Buna, M.; Strazza, C.; Olivieri, N.; Stevens, T.; Peeters, L. DG RTD-TRL Project Technology Readiness Level: Guidance Principles for Renewable Energy Technologies Final Report; European Commission: Brussels, Belgium, 2017; ISBN 978-92-79-59753-4.

64. Faltinsen, O.M. Hydrodynamics of marine and offshore structures. J. Hydrodyn. 2015, 26, 835-847. [CrossRef]

65. Odd, M.; Faltinsen, M.L.; Greco, M. Slamming in marine applications. J. Eng. Math. 2004, 48, 187-217.

66. Bhattacharyya, R. Dynamic of Marine Vehicles; John Wiley \& Sons, Inc.: New York, NY, USA, 1978.

67. Saincher, S.; Banerjee, J. Influence of wave breaking on the hydrodynamics of wave energy converters: A review. Renew. Sustain. Energy Rev. 2016, 58, 704-717. [CrossRef]

68. Bonar, P.A.J.; Bryden, I.G.; Borthwick, A.G.L. Social and ecological impacts of marine energy development. Renew. Sustain. Energy Rev. 2015, 47, 486-495. [CrossRef]

69. Silva, R.; Martínez, M.L.; Hesp, P.A.; Catalan, P.; Osorio, A.F.; Martell, R.; Fossati, M.; da Silva, G.; Mariño-Tapia, I.; Pereira, P.; et al. Present and future challenges of coastal erosion in Latin America. J. Coast. Res. 2014, 71, 1-16. [CrossRef]

70. McCauley, D.J.; Pinsky, M.L.; Palumbi, S.R.; Estes, J.A.; Joyce, F.H.; Warner, R.R. Marine defaunation: Animal loss in the global ocean. Science 2015, 347, 1255641. [CrossRef] [PubMed]

71. Jones, K.R.; Klein, C.J.; Halpern, B.S.; Venter, O.; Grantham, H.; Kuempel, C.D.; Shumway, N.; Friedlander, A.M.; Possingham, H.P.; Watson, J.E.M. The location and protection status of earth's diminishing marine wilderness. Curr. Biol. 2018, 28, 2506-2512. [CrossRef]

72. Silva, R.; Lithgow, D.; Esteves, L.S.; Martínez, M.L.; Moreno-Casasola, P.; Martell, R.; Pereira, P.; Mendoza, E.; Campos-Cascaredo, A.; Winckler Grez, P.; et al. Coastal risk mitigation by green infrastructure in Latin America. Proc. Inst. Civ. Eng. Marit. Eng. 2017, 170, 39-54. [CrossRef] 
73. Yates, K.L.; Schoeman, D.S.; Klein, C.J. Ocean zoning for conservation, fisheries and marine renewable energy: Assessing trade-offs and co-location opportunities. J. Environ. Manag. 2015, 152, 201-209. [CrossRef] [PubMed]

74. Mendoza, E.; Lithgow, D.; Flores, P.; Felix, A.; Simas, T.; Silva, R. A framework to evaluate the environmental impact of OCEAN energy devices. Renew. Sustain. Energy Rev. 2019, 112, 440-449. [CrossRef]

75. Jenkins, C.N.; Van Houtan, K.S. Global and regional priorities for marine biodiversity protection. Biol. Conserv. 2016, 204, 333-339. [CrossRef]

76. Neill, S.P.; Robins, P.E.; Fairley, I. The impact of marine renewable energy extraction on sediment dynamics. In Marine Renewable Energy: Resource Characterization and Physical Effects; Springer: Cham, Switzerland, 2017; ISBN 9783319535364.

77. Boehlert, G.W.; Gill, A.B. Environmental and ecological effects of ocean renewable energy development: A current synthesis. Oceanography 2010, 23, 68-81. [CrossRef]

78. Copping, A.E.; Sather, N.K.; Hanna, L.; Whiting, J.; Zydlewski, G.B.; Staines, G.; Gill, G.; Hutchison, I.; O'Hagan, A.M.; Simas, T.; et al. Annex IV 2016 State of the Science Report: Environmental Effects of Marine Renewable Energy Development around the World; Ocean Energy Systems: Lisbon, Portugal, 2016; p. 199.

79. Taormina, B.; Bald, J.; Want, A.; Thouzeau, G.; Lejart, M.; Desroy, N.; Carlier, A. A review of potential impacts of submarine power cables on the marine environment: Knowledge gaps, recommendations and future directions. Renew. Sustain. Energy Rev. 2018, 96, 380-391. [CrossRef]

80. Walsh, J.; Bashir, I.; Garrett, J.K.; Thies, P.R.; Blondel, P.; Johanning, L. Monitoring the condition of marine renewable energy devices through underwater acoustic emissions: Case study of a wave energy converter in Falmouth Bay, UK. Renew. Energy 2017, 102, 205-213. [CrossRef]

81. UN Environment. Assessing Environmental Impacts-A Global Review of Legislationn, Nairobi, Kenya; UN Environment Law Division and UN Environment World: Nairobi, Kenya, 2018; ISBN 978-92-807-3679-3.

82. United Nations. UN 7 Affordable and Clean Energy; United Nations: New York, NY, USA, 2016.

83. Edelman, A.; Gedling, A.; Konovalov, E.; McComiskie, R.; Penny, A.; Roberts, N.; Templeman, S.; Trewin, D. 2014 Report; James Cook University: Cairns, Australia, 2014.

84. Halpern, B.S.; Frazier, M.; Potapenko, J.; Casey, K.S.; Koenig, K.; Longo, C.; Lowndes, J.S.; Rockwood, R.C.; Selig, E.R.; Selkoe, K.A.; et al. Spatial and temporal changes in cumulative human impacts on the world's ocean. Nat. Commun. 2015, 6, 7615. [CrossRef]

85. UNDP (United Nations Development Programme). Human Development Index (HDI); United Nations Development Programme: New York, NY, USA, 2018.

86. UNDP (United Nations Development Programme). Human Development Data. Available online: http: //hdr.undp.org/en/data (accessed on 20 December 2018).

87. CIESIN (Center for International Earth Science Information Network). Urban-Rural Population and Land Area Estimates Version 2. Available online: http://sedac.ciesin.columbia.edu/data/set/lecz-urban-ruralpopulation-land-area-estimates-v2 (accessed on 20 December 2018).

88. Mendoza, E.; Chávez, X.; Alcérreca-Huerta, J.C.; Silva, R. Hydrodynamic behavior of a new wave energy convertor: The Blow-Jet. Ocean Eng. 2015, 106, 252-260. [CrossRef]

(C) 2019 by the authors. Licensee MDPI, Basel, Switzerland. This article is an open access article distributed under the terms and conditions of the Creative Commons Attribution (CC BY) license (http://creativecommons.org/licenses/by/4.0/). 